\title{
From Consciousness toward Self-Consciousness: The Byronic Hero as the Hegelian Slave
}

\author{
Marziyeh Farivar ${ }^{1}$, Shanthini Pillai ${ }^{1}$, Roohollah R. Sistani ${ }^{1}$ \& Masoumeh Mehni ${ }^{2}$ \\ ${ }^{1}$ School of Language Studies and Linguistics, UKM, Malaysia \\ ${ }^{2}$ University Putra Malaysia, Malaysia \\ Correspondence: Marziyeh Farivar, School of Language Studies and Linguistics, UKM, Malaysia. E-mail: \\ oceanblue_mf@yahoo.co.uk
}

Received: May 7, 2013 Accepted: June 5, 2013 Online Published: July 19, 2013

doi:10.5539/res.v5n4p61

URL: http://dx.doi.org/10.5539/res.v5n4p61

\begin{abstract}
This paper attempts to present the journey of the Byronic Hero's consciousness toward self-consciousness in "The Prisoner of Chillon" and "Mazeppa". In this regard, Hegel's uppermost notion about lordship-bondage as stated in "The Phenomenology of Spirit" is applied to these narrative verses while concentrating on the interaction and relationship of the Byronic Hero and the environment. The lordship-bondage notion, emphasizing freedom, dependency and independency, maps the development of one's consciousness toward self-consciousness in which one acquires knowledge and independency. Lordship-bondage is a reciprocal relationship in which one confronts another being and sets a struggle in order to establish and maintain the superiority and dominance. Hegel's illustration of lordship-bondage is primarily known as master-slave , comprising three stages of confrontation: recognition and acceptance highlighted within the three phases of thesis, anti-thesis, and synthesis. As these terms merge together, one's consciousness is observed through them and through interacting with another consciousness to clarify contradictory manifestations of the two people. Hence, the Byronic Hero's self-consciousness is portrayed to present him as the Hegelian Slave. As an interdisciplinary study, his interaction with the environment is analyzed based on the mentioned framework.
\end{abstract}

Keywords: Byronic Hero, Hegelian master-slave dialectics, self-consciousness, lordship-bondage

\section{Introduction}

Described as "attractive and dangerous" (Quinn, 2006) and having come into being through creating "The Childe Harold's Pilgrimage", the Byronic Hero is the crux of Lord Byron's poetical works as well as of the Romantic period as he was followed later on throughout the literature of the time and of the modern era. It has been mentioned that the Byronic Hero's origin goes back to Milton's Lucifer as he possesses satanic qualities that are an "amalgam of the Aristotelian tragic hero and other heroic elements"(Douglas, 2004). However, the Byronic Hero is much more extolled within the Gothic literature and Romantic tradition. It is deemed that Lord Byron did not create it mechanically in order to show and to expose himself to the world outside and it "did not spring by a miracle of parthenogenesis from" his mind (Thorslev, 1962).

The performed studies and researches associated with "The Byronic Hero" have furnished various other definitions and connections to such a character when it is stated that he is a lonely, self-exiled, rebellious one. Stephanie Mendoza (2009) refers to the presentation of the Byronic Hero in the modern media as the character of Edward Cullen in "Twilight" resembles him very much. "The Byronic Hero in Film, Fiction and Television" by Stein (2004) refers to the Byronic Hero "as an outlaw and an outsider who defines his own moral code..." (Stein, 2004); besides, Stein has expressed the resemblance of the Byronic Hero to the Bronte's' heroes, and to Dracula as well. Jiang Chengyong (2010) presents the Byronic Hero as the manifestation of Byron's rejection of civilized society and his culturally romantic attitude (Chengyong, 2010).

Furthermore, in "A novel vocabulary: Byronic hero into Don Juan", Emma Peacock 2010 states that Byron's hero is the expression of "sexual discourse" and the projection of "sorrow and frustration as well as desires" (Peacock, 2010). Byronic hero was the outcome of a sick body and mind according to the writer and he could poison anybody within the enthusiastic public. Besides, Lokash (2007), added that Byronic hero was a character who channeled all the painful experiences of Byron himself and made him forget about his physical deformity 
which emphasized on the ancient argument about therapeutic effect of creation of art as well as reading it. "If poetry is a disease, however-Byron also depicts it as a potential cure-or at least as offering some form of relief through expression" (Lokash, 2007). In this case Margaret Daniel (2004) called the Byronic Hero the historical, political and social product of the time. While the researcher has concentrated on the "Turkish Tales", she demonstrated that Byron's biography and the political and social circumstances of the time would have been highly influential for creation of the Byronic Hero which has made him the cultural icon.

The Byronic hero in the narrative verses of "The prisoner of Chillon" and "Mazeppa" is presented in two distinguished ways of primarily objective and then subjective narrative style. It means that the first stanzas of the verses are narrated from the third person point of view while introducing characters and setting as the preparative steps to observe the Byronic Hero by itself. The characters of the prisoner and Mazeppa are identified as the Byronic Hero in the sense that both possess some characteristics of the Byronic hero in terms of being passionate, strong, rebellious, exiled, and nostalgic and having a mysterious past. Byron wrote "The Prisoner of Chillon" and "Mazeppa" in 1816 and 1819 respectively.

Set away and far from Britain, both of these narrative verses portray the struggles and challenges through which the Byronic Hero goes through the journey of self-perception and self-understanding. The journey undertaken by the Byronic Hero is one which reflects how he acquires knowledge and self-consciousness. In portraying such a journey, Hegelian master-slave dialectics is applied to observe the Byronic hero through the stages of confrontation, recognition and acceptance which are adapted to three phases of thesis, anti-thesis, and synthesis.

\section{Theoretical Framework}

Hegelian master-slave dialectics is a part of "Phenomenology of Spirit" in which he philosophically sketches the movement of consciousness towards gaining absolute knowledge, which implies becoming self-conscious. Hegel himself describes his project as 'the exposition of knowledge as a phenomenon' because he sees the development of consciousness as a development toward forms of consciousness that more fully grasp reality, culminating in 'absolute knowledge (Singer, 1983).

Succinctly, this theory sheds light on the way two consciousness confront each other as it is externally and internally necessary to face another self-consciousness which leads to their engagement within the struggle for maintaining the authority. Hegel wrote in the "Phenomenology of Spirit" (1978) that "Self-consciousness exists in and for itself when, and by the fact that, it so exists for another; that it exists only in being acknowledged". This indicates that there must exist another being, for confrontation requires two to struggle or to "Force" and to acknowledge each other's position (Hegel, 1978). He furthermore added that "They must engage in the struggle, for they must raise their certainty of being for themselves to truth, both in the case of the other and in their own case..." (Hegel, 1978).

One submits in order to survive and becomes slave and the other establishes his/her authority in order to rule. However, the slave finds his/her freedom by giving and providing service to the master which makes him independent and the other one becomes dependant and a slave. Hegel puts it into words in this way that "just where the master has effectively achieved lordship he really finds that something has come about quite different from an independent consciousness. It is not an independent, but rather a dependent consciousness that he has achieved" (Hegel, 1978). He adds the master who was assumed to be independent becomes slave to the slave and that "through work . . . the bondsman becomes conscious of what he truly is" (Hegel, 1978). The following section includes two distinguished analyses of "Mazeppa" and "The Prisoner of Chillon" and concentrates on the Byronic Hero to observe how he develops and moves and becomes the Hegelian slave.

\section{Analysis}

\subsection{Mazeppa}

Mazeppa, the Ukraine's hetman, is described as "rough, and scarce less old... calm and bold" in stanza III, lines 55-56, where he appears accompanying Charles coming back from the war. Charles makes a comparison between him and his other men and says Mazeppa is "...firm of heart and strong of hand, / In skirmish, march, or forage, ... (IV, 98). And that no one was ever seen to like him "since Alexander's days till now" (IV, 103). This first picture instantly suggests Mazeppa is someone who has been through and has been transformed by hard times into a physically strong man. The story of his life that he narrates, though related to the past, reveals how he changed and what he had experienced so far. It can be said that Mazeppa is self-conscious about his qualities and his life story, which includes a short section associated with him trying not to submit to the self and environment. 
Mazeppa says that he was a loyal and faithful attendant to Casimir who was the King (IV). He refers to Casimir as someone far from Royalty and a magnificent King; he clarifies his comparison of Charles and Casimir in this way:

He made no wars, and did not gain

New realms to lose them back again;

And (save debates in Warsaw's diet)

He reigned in most unseemly quiet;

Not that he had no cares to vex,

He loved the muses and the sex (IV, 133-138).

Such a description about the King makes him appear as self-certain and conscious, whose whole world is limited to what he owns and possesses and for this reason he sees himself as a free man. In addition, he wishes he could have been in the war and he is angry for not being so; yet he finds his comfort and resolution in getting a new mistress and in celebrating:

They made him wish himself at war;

But soon his wrath being o'er, he took

Another mistress - or new book;

And then he gave prodigious fetes-

All Warsaw gathered round his gates

To gaze upon his splendid court,

And dames, and chiefs, of princely port (IV, 140-146).

Then Mazeppa pictures his court as being as "a court of jousts and mimes / where every courtier tries at rhymes" (IV, 152-153). Thus the first connection and interaction of Mazeppa is with a court and a king that do not connote power and authority.

Meanwhile, he describes himself as young, strong and smooth and completely different from his present status. He feels he is quite safe and useful in the King's court as no one could be a match for him in terms of his prudence and quickness in doing the job. He refers to himself as a "vassal" which shows he is conscious about his bond to the King and the dependency due to the work done and service provided by him. Based on Hegelian master-slave dialectics, Mazeppa's consciousness defines him as a slave to the master though the master is within the slave pattern by the characteristics pictured by Mazeppa.

Obviously, Mazeppa's freedom in the first place rests on the works he is doing; yet his digression and deviation from his limitation and boundaries brings about consequences in which his freedom and independency are by far gone. He falls in emotional relationship with the King's wife which is morally and basically inappropriate. He describes her in this way:

The shape of her I loved so well:

She had the Asiatic eye,

Such as our Turkish neighbourhood,

Hath mingled with our polish blood,

Dark as above us is the sky;

But through it stole a tender light,

Like the first moonrise of midnight;

Large, dark, and swimming in the stream,

Which seemed to melt to its own beam..." (V, 207-215).

Their mutual feeling started as the woman was tired of been dominated by the King as husband; so she fiercely developed her feeling for Mazeppa. This idea of switching from one man to another one because of demanding support and emotion would be one point that deserves discussion in the margin in the sense that the woman needed bond and connection; that without being chained as a lover, she could not carry on living. 
Mazeppa explains that he tried to keep his distance although he felt a "burning chain that binds/Without their will, young hearts and minds..." (VI, 240-241) and he “... sighed - in silence wept..." (VI, 244). Then he became closer to her in order to reveal his love; so they met in secret but were spied and seized on the spot. As a result, Mazeppa is condemned, ignored and denied any right as well as his job. This phase reflects one step of his struggle, which makes him being close to recognition.

In making the primary analysis, it must be said the journey of Mazeppa's consciousness from the beginning till this point is about the way he gets his self-consciousness through interacting with the King and the King's wife. $\mathrm{He}$ is self-certain at first as he thinks the knights may not be able to compete with him. The King is himself delusional as he is unable to see beyond women and celebration, which is inappropriate for a King. On the other hand, Mazeppa is his servant physically and as he is punished due to his guilt, he is unable to act or to decide. He prays and seeks succor from a goddess or deity.

The king commands him to be fastened on horseback:

"They bound me on, that menial throng,

Upon his back with many a thong;

They loosed him with a sudden lash -

Away! - away! - and on we dash! -

Torrents less rapid and less rash (IX, 270 -374).

From this point his struggle with environment and self begins. The horse is described as wild, fast and fierce, belonging to the Ukraine breed. This harsh journey is carried on through rivers, trees, stones, bridges, towns and fields that show the hardship and agony Mazeppa is taking. Due to being tightly and roughly fastened, there is some bleeding over his body, which makes him dramatically fearful and thirsty.

He is half awake but he is consciously feeling and experiencing the difficult situation, sometimes he wishes he could have a knife or a sword in order to kill himself; sometimes he feels he may fall but he tries not to. In addition, he tries to keep himself tied to the horse:

The boughs gave way, and did not tear

My limbs; and I found strength to bear

My wounds, already scarred with cold -

My bonds forbade to loose my hold (XII, 487-490).

He describes the movement of horse through the trees and boughs like wind while various disturbing emotions such as sorrow, cold, shame, distress and hunger described as tortures come to him. He expresses the torture he is receiving as dying over and over again as he says the ride and environment, both, make him wonder whether he is alive. The struggle of life and death about Mazeppa reflects the dialectics which push him to submit rather than die. The picture he describes about a flying raven is shockingly deep; he says:

I cast my last looks up the sky,

And there between me and the sun

I saw the expecting raven fly,

Who scarce would wait till both should die (XVIII, 768-771).

The raven symbolizes the idea of death and Mazeppa's feeling about death while unsaved is intensified. The bird keeps flying over him and he sometimes sees it coming closer. He tries to show that he is still alive by revealing "throat's faint struggling noise"; even if it is far from being a voice but he finds it effective in keeping the raven away.

The last stanza of the narrative verse reveals how he is saved, which starts with him wondering and asking himself about the place, the closed roof above his head and "... mortal yon bright eye/ That watches me with gentle glance? (XIX, 801-802). Mazeppa says "I gaze, and gaze, until I knew/ No vision it could be..." and then he realizes being saved by Cossacks from a "vulture feast" and he becomes the "Cossack's guest" (XIX).

Mazeppa's imposed journey, precisely entitled punishment for his affair, puts him in a difficult while he is physically unable to act and to move. In the first place, he is seen to be conscious of his situation; he is in the service of the King, which makes him potentially free based on master- slave dialectics. This may be called his confrontation phase where he knows and understands his boundaries and he thinks he gets the attractions of 
knights too. In this stage, Mazeppa is the bondsman providing products to the king; yet he establishes his independency as well as the dependency of the King on his service. This confrontation phase is precisely the thesis part of Hegelian dialectics in which Mazeppa knows himself as inferior but perceives himself as superior. He presumes by doing a job for his Lord, he can maintain his own independency but he breaks the boundaries and rules that both make him safe and limit him, which leads to his punishment.

When Mazeppa is sent to the wild naked and tied on horseback, the phase of recognition is initiated while his confrontation continues into a different situation which extensively echoes an anti-thesis phase.

Mazeppa's guilt is irreparable and the King cruelly sentences him to be tied on the back of a wild Ukraine horse, which may imply that the King relents and does not kill him right away. Yet, this punishment is far worse than instant death. The journey begins and continues as he experiences pain, despair and sorrow. He struggles to stay awake and alive and he keeps hoping to see some people in order to survive. The horse travels and passes through the trees, bushes and various plants which intensifies Mazeppa's suffering and pain. He describes the fastness of the horse as "meteors through the sky/ When with its cracking sound the night/ Is chequered with the northern light..." (XI). He understands that he may not survive it as the wild horse does not seem wanting to rest and it becomes more furious with any movement or sound performed by from Mazeppa. He tries to master the horse but it is unable to do so as his situation becomes worse.

When the horse enters the Siberian forest, Mazeppa understands that he is going into a location where the environment is harsh, lifeless, cold, bleak and wild and that there is "no trace of man" (XII). His struggle to be free from the horse bears the idea of keeping the self alive, which recalls master-slave dialectics in the sense that the slave submits to the master because he/she wants to stay alive. Thus he consciously submits to the horse to lead the way and go forward in order to possibly find people. The dependency on the horse's life is the key to being alive despite the hardship he faces. However, it must be noted that Mazeppa's development of consciousness from the primary self-certainty of being independent toward the knowledge of being dependant reveals his recognition of growing.

So far, the thesis within the confrontation phase has pictured him as an independent and confident man who crosses the defined lines of loyalty and is sentenced to be fastened on the back of a horse; which itself moves to the anti-thesis phase of contemplating self.. The confrontation phase smoothly moves toward the recognition phase as Mazeppa experiences impending death and suffers unbearable situations. He finds out that he is unable to lead the horse though he fights to be alive.

The last phase of dialectics, which is synthesis, embodies how recognition is fulfilled in addition to how Mazeppa accepts his role as a slave. He gets the knowledge as he yields to the environment; his consciousness takes on the journey from a confidant restricted slave toward a self-confident self-conscious slave. Although the word slave is repeated, the condition is absolutely different in terms of being aware of boundaries, limitation and superiority of outside power. He is now a subject of King Charles XII of Sweden which apparently sets him in the slave position; yet not only is he taking the King's orders and accepting his commands but he is accepting his role as a self-consciousness slave as well.

\subsection{The Prisoner of Chillon}

The setting of the story is based on a real prison located on the banks of Lake Geneva in Switzerland. Byron was inspired by this place when he was with Percy Shelly. The place has a historical reference as it is about a 16th century patriot, Francois Bonnivard, imprisoned because he fought for freedom, liberty and justice. However, the story is literarily imaginative reflecting the state of mind, emotions, mental challenges and thoughts of a prisoner about the self as well as the world around. It must be noted that the setting has a salient role.

The prison is located underground while it is surrounded by lake water as well. It is dark, old and dreary. The prisoner is chained along with his three brothers but they are individually chained to the pillars. He describes his brothers and the fact that he is the elder one and thus he must give them hope to survive. They died and then the prisoner begins speculating and conceptualizing himself and the environment. The story hints at the way the prisoner is consciously and unconsciously involved within the environmental bondage and dependency in terms of family, place and guards.

The master-slave dialectics in "The Prisoner of Chillon" is disclosed through the prisoner's interaction with the environment. His reaction to and relationship with the environment in terms of family, guards and the prison, consciously and unconsciously, change profoundly. And so the description of the prison as a practical situation seems a central aspect of the master-slave analysis. 
The prison is highly influences how the narrator goes through confrontation, recognition and acceptance. Concisely, there is one significantly complex master-slave pattern in the poem to consider: the narrator and the environment. The environment may define itself in terms of prison, guards, and family.

The prison, Chillon, is well described by the narrator. It is "gothic", "damp", "dull" and "old". He says that there is a lake called "Leman" around the prison walls. It is like a "living grave" where the prisoners are kept. It is so dark that:

A sunbeam which hath lost its way,

And through the crevice and the cleft

Of the thick wall is fallen and left;

Creeping o'er the floor so damp..." (II, 5-8).

Light is generally a symbol of hope, freedom, authority and knowledge. These lines picture the light as being unable to reflect its true identity and function. It loses its way and it is unable to light and warm up the prison. The prison floor is wet and damp and the light cannot change such a condition. The darkness and dampness of the prison affect the prisoner consciously.

The prison seems to control the narrator's consciousness. Its role is like that of a lord exercising power over the prisoner. The physical aspects of prison weigh on him both physically and mentally. He says:

There are seven pillars of Gothic mould,

In Chillon's dungeons deep and old,

There are seven columns, massy and grey,

Dim with a dull imprison'd ray (II, 1-4)

Or,

And in each pillar there is a ring,

And in each ring there is a chain;

That iron is a cankering thing,

For in these limbs its teeth remain,

With marks that will not wear away (II, 11-15)

The above lines present some characteristics of the prison. "Deep" and "old", "massy" and "gray" and the dim light reflects his physical and mental confinement. The structure and the ] seven pillars seem both frightening and intensely dark. The implication of the word "dungeon" is quite reflective. This horrifying place seems to occupy the unconscious faculty of the prisoner.

Furthermore, there are marks from the chain teeth on his hands which will not fade away. Not only is confined in the dark and dim dungeon but also the chains render him immobile as well. He expresses the burden of the "cankering thing" on him, that even if he is free in the future the marks will never fade away and they will mentally be the unconscious memory of physical and mental confinement. The marks will be the reminder of the years and pains of imprisonment. These images reveal that the narrator is controlled and he is not free. He is both consciously and unconsciously affected. He is a slave to the place.

Later on, in stanza VI of the poem, the narrator describes the prison and the region more, saying that Chillon's walls are surrounded by deep and massy water and as a result: "A double dungeon wall and wave / Have made and like a living grave" (VI, 7-8)

The walls of the dark and damp dungeon are double folded. Although this picture is a physical face of the dungeon, the "double dungeon wall" and its resemblance to a "grave" suggest the immeasurable sense of claustrophobia and restriction. While the movement of water might be liked by people, the sound of water, in the dungeon, on the other hand, seems like a load upon the narrator's mind:

Below the surface of the lake

The dark vault lies wherein we lay:

We heard it ripple night and day (VI, 9-11)

There is a line "They chain'd us each to a column stone" in the first part of the poem in which the narrator refers to the pronoun "they". It indicates that there are people as guards that provide chains and physical bonds. 
Although at the end of the poem, they are no longer considered as master, through the poem, 'they' are the sign of lordship that is able to determine the life, death and freedom and bond of the prisoner.

The poem is told from the first person point of view. The "I" is the narrator. The narrator is a man who has been imprisoned for a long time. He starts the poem by describing himself in this way:

My hair is grey, but not with years,

Nor grew it white

In a single night,

As men have grown from sudden fears:

My limbs are bow'd, though not with toil,

But rusted with a vile repose...(I, 1-6)

These lines portray him as being considerably affected by the long period of confinement. His natural and original shape has been changed as a result of such hardship and the absence of life and spirit in such a dark and dreadful dungeon. Being kept in prison has led to this condition. It means that his physical appearance appears older than he really is because of both mental and physical confinement and suffering. Such depiction illuminates how the prison exercises power over the prisoner.

In another sense, these lines elucidate the narrator's existing situation. He describes his chained body that has been deprived of the very idea of freedom. He is a slave both physically and psychologically. Another aspect of this environment, where the prisoner is dealing with through the phase of confrontation is family members. He has been imprisoned along with his three brothers. And each one of them is chained in a way that does not allow them to see one another: "We could not move a single pace / We could not see each other's face (III, 3-4)

He even says that the "pale" light inside the prison makes them "strangers" in their "sight". Yet they could speak to each other:

And each turn comforter to each

With some new hope, or legend old,

Or song heroically bold (III, 12-14).

He describes how his three brothers gave up living and died. The way they lived and died as described by the narrator shows him being highly attached to them. They are portrayed as "pure", "bright", "free", "mighty" and "strong". While he is drawing distinguished picture of each brother he is revealing his own characteristics as well.

He is attached to his brothers. He is the eldest brother; hence he assumes a responsibility to support them. The blood-relationship implies bondage and dependency. Such dependency binds him to their memories and conditions.

Based on the confrontation phase of Hegelian master-slave dialectics, the narrator is in the situation of a prisoner and a slave. He is chained, his brothers are chained too. His father was burnt at the stake and the other three brothers were murdered. They died because they held to their beliefs and they did not want to be slaves to the beliefs of others or be subordinated by the prevailing powers. The prisoner is attached to his family. There is a bond which makes him dependant and as a result he encounters various elements that make him unable to consciously decide, think or react. The picture he draws in his mind about the prison is surprisingly vivid and expressive. It shows how much he is under the control of the environment.

The recognition phase of the narrative poem occurs as his brothers gradually begin to die one by one. Although he feels bitter, unconsciously he comes to recognize that he is released from the load of agony. In section XI of the poem, he says: "A kind of change came in my fate / My keepers grew compassionate (XI, 1-2).

His "keepers" treat him rather less harshly after the passing of his brothers. He is unable to understand why they have become thus as they were harsh on them all. The prisoner is not watched as closely as before and he is able to walk. This stage is the transition of both the prisoner and the environment from recognition toward acceptance.

The narrator has lost his brothers and while he was walking he carefully avoids his brothers' graves. He says:

For if I thought with heedless tread

My step profaned their lowly bed, 
My breath came gaspingly and thick,

And my crush'd heart felt blind and sick (XI, 15-18).

The lines depict how deeply he is affected by the death of his brothers. He does not have anyone anymore and he feels he is extremely alone:

Lone as the corpse within its shroud,

Lone as a solitary cloud,

A single cloud on a sunny day,

While all the rest of heaven is clear,... (X, 43-46).

Here, he comes to a kind of revelation which contributes to the whole frame of recognition and acceptance. He says: "No child, no sire, no kin had I, / No partner in my misery (XII, 8-9). He comes to understand and recognize his situation. The feeling of not having any close blood-relatives makes him recognize that there is no bond. Before, he took care of his brothers by not letting them feel disappointed and by not letting them surrender to death. But he has lost them all and is left alone. Although such feelings are not positive, they lead him to feel independent. Earlier, in his confinement and with the presence of the guards, he had felt anxious and stressful. But he recognizes the circumstances consciously; accepts it and acknowledges that: "And the whole earth would henceforth be / A wider prison unto me... (XII, 6-7).

When he achieves the recognition of self and understands his consciousness, he does not think about the prison as a limited and restricted place that holds him physically and psychologically. He is then able to see a bigger picture. According to the lines, above, he makes no difference between the prison of Chillon and the world. And then he expresses how, earlier, he was "mad", furious and troubled by thinking about them but now, he perceives the environment as altered. He is no longer doomed to be separated from nature because of his confinement:

But I was curious to ascend

To my barr'd windows, and to bend

Once more, upon the mountain high,

The quiet of a loving eye.

I saw them - and they were the same

They were not changed like me in frame;

I saw their thousands years of snow

On high - their wide long lake below,

And the blue Rhone in fullest flow... (XII, 11-19).

The last section of the poem, profoundly and significantly, illustrates the state of truth he has achieved which denotes the acceptance phase. It indicates that he recognizes himself as a slave due to the fact that each single space would mean a restraint for him and describes this feeling thus:

At last men came to set me free;

I asked not why, and reck'd not where;

It was at length the same to me,

Fetter'd or fetterless to be,

I learn to love despair (XIV, 5-9).

He does not see any difference between being chained and being unchained, which is as a result of the realization of self and his circumstance. He becomes dependent through physical and mental bondage or situational power or authority. The walls which confine him mean much more than mere physical prison walls:

And all my bonds aside were cast,

These heavy walls to me had grown

A hermitage - and all my own! (XIV, 11-13).

He chooses and accepts the dungeon to stay as his home. He compares himself to the spiders and rats moving in the dungeon and believes that if they are satisfied with their home "And why should I feel less than they?" He refers to the prison as his hermitage, which belongs to him and of which he is a part. 
In the last lines of the poem, the narrator refers to himself as "the monarch of each race", able to conduct and to command any kind of action. He says that there are situations which are not approved and satisfactory for man, but these situations are the circumstances that are required "To make us what we are". It implies that although confrontation embodies hardship, death and confinement, recognition and acceptance, however, bestow understanding and realization about self and environment to man. And at last he declares: “...-even I /Regain'd my freedom with a sigh (XIV, 26-27).

He finds and realizes the truth within the prison, and as he accepts his situation, he is no longer assumed as a prisoner or a slave to certain political powers of particular people; he, on the other hand, sees himself as self-conscious of being imprisoned within his own truth.

\section{Conclusion}

Observing Mazeppa and the Prisoner based on Hegelian master-slave dialectics provides a novel philosophical view toward researches associated with Lord Byron. Both of these characters are assumed as being the Byronic Hero as they present particular characteristics and traits of this character in terms of being contemplative, nostalgic, emotional and dreamy, romantic and rebellious and being exiled. When Hegelian master-slave dialectics is applied, these characters' interactions and relations toward other characters, mainly to those in power, are analyzed through three stages of confrontation, recognition, and acceptance. Their consciousness is in the state of certainty in the first place; yet by confronting other sources of power and struggling to establish and to secure their place, they come to recognize and to accept that they must submit in order to embrace life. Mazeppa and the Prisoner, therefore, possess the qualities of the Hegelian slave.

While the limitation of the present study rests on merely applying the absolute philosophical theory of Hegel as it concisely involves master-slave dialectics, the writer recommends a combination of the aforesaid theory with psychological and post-colonial theories in order to view Byron's works and characters in a new light. In addition, the further researches and articles may accordingly include the female characters as well.

\section{References}

Chengyong, J. (2010). The Byronic Hero and the Archetype of Superman: On Byron's Cultural Values. Foreign Literature Studies, 32(6), 55-63.

Daneil, M. (2004). The Byronic Hero as Cultural Icon in The Romantic Period. University of Malaya.

Douglass, P. (2004). THE CAMBRIDGE COMPANION TO BYRON. UK: Cambridge University Press.

Hegel, G. W. F. (1978). The Phenomenology of Spirit. Oxford: Oxford University Press.

Kenneth, H. O., \& Warren U. O. (1973). Žukovskij's Translation of The Prisoner of Chillon. American Association Of Teachers Of Slavic And East European Languages The Slavic And East European Journal, 17(4), 390-398.

Lokash, J. (2007). Byron and the Pathology of creativity. Journal of Literature and Science, 1(1), 24-39. http://dx.doi.org/10.12929/jls.01.1.02

Maurice, S. C. (Ed.). (1905). Prisoner of Chillon, Mazeppa and other Selections from Lord Byron. Boston: Sibley and Company.

Mendoza, S. (2009). From Dawn to Twilight: The Byronic Hero. Theocrit: The Online Journal of Undergraduate Literary Criticism and Theory, 1(1), 9-24.

Peacock, E. (2010). A novel vocabulary: Byronic hero into Don Juan. Anthropoetics, 15(2). http://dx.doi.org/anthropoetics.ucla.edu/ap1502/1502Peacocke.htm

Quinn, E. (2006). A dictionary of Literary and Thematic terms (2nd ed.). New York: Infobase Publishing.

Singer, P. (1983). Hegel. Oxford: Oxford University Press.

Stein, A. (2004). The Byronic Hero in Film, Fiction and Television. Carbondale: Sothern Illinois University Press.

The Prisoner of Chillon by Lord Byron. (2001). Retrieved from http://www.blackmask.com

Thorsleve, P. (1962). The Byronic Hero: Types and Prototypes. Minneapolis: Minnesota Press.

West, D. (2001). The transition and transformation from Byronic hero to the superfluous man. The Routledge Companion to Russian Literature. Retrieved from http://engling.truman.edu/SeniorSem/PDFpapers/West\%20paper\%20PDF.pdf 


\section{Copyrights}

Copyright for this article is retained by the author(s), with first publication rights granted to the journal.

This is an open-access article distributed under the terms and conditions of the Creative Commons Attribution license (http://creativecommons.org/licenses/by/3.0/). 